\title{
Faktor yang Berpengaruh Terhadap Disease Free Survival dan Overall Survival pada Pasien Kanker Payudara Usia Muda di Kota Padang Tahun 2008 - 2018
}

\author{
Magdi Ayuza ${ }^{1}$, Wirsma Arif Harahap, ${ }^{1}$ Rony Rustam, ${ }^{1}$ Richvan Dana Nindrea ${ }^{2}$
}

\begin{abstract}
Abstrak
Kanker Payudara (KPD) pada usia muda memiliki keistimewaan karakteristik. Rekurensi KPD dipengaruhi oleh berbagai faktor antara lain faktor klinis, regimen terapi dan biomolekuler dari tumor itu sendiri. Berbagai macam modalitas terapi KPD, namun masih terdapat risiko terjadinya rekurensi terutama pada pasien dewasa muda. Tujuan: Mengetahui faktor-faktor yang mempengaruhi Disease Free Survival (DFS) dan Overall Survival (OS) pada pasien KPD usia muda di Kota Padang. Metode: Penelitian ini menggunakan desain cohort study retrospectif pada pasien KPD usia muda yang telah mendapatkan pengobatan KPD yang memenuhi kriteria inklusi sebanyak 103 sample yang terdapat pada data register KPD PERABOI Padang. Analisis survival menggunakan Kaplan Meier dengan Log Rank Test. Apabila diperoleh nilai $\mathrm{p}<0,05$, maka terdapat hubungan bermakna. Hasil: Terdapat perbedaan antara setiap faktor klinis, faktor biomolekuler dan faktor terapi dalam hal rata-rata DFS maupun rata-rata OS, namun tidak terdapat pengaruh yang bermakna secara analisis statistik antara faktor terapi (terapi hormon, radioterapi dan terapi target) terhadap DFS dan OS pada pasien kanker payudara usia muda di Kota Padang ( $p>0,05)$. Terdapat pengaruh dari pemberian kemoterapi terhadap DFS pada pasien kanker payudara usia muda di Kota Padang $(p<0,05)$. Simpulan: Tidak terdapat hubungan yang bermakna antara faktor klinis dan faktor biomolekuler dengan DFS dan OS, namun terdapat hubungan bermakna antara pemberian kemoterapi dengan DFS dan OS pada penderita KPD usia muda di kota Padang tahun 2008 - 2018.
\end{abstract}

Kata Kunci: kanker payudara, terapi kanker payudara, faktor rekurensi

\begin{abstract}
Breast Cancer $(B C)$ at a young age has characteristic features. $B C$ recurrence is influenced by various factors including clinical factors, therapeutic and biomolecular regimens of the tumor itself. There are various modalities for KPD therapy, but there is still a risk of recurrence, especially in young adult patients. Objectives: To determined the factors that influence Disease Free Survival (DFS) and Overall Survival (OS) in young BC patients in Padang. Methods: This study used a retrospective cohort study design in young $B C$ patients who had received $B C$ treatment that met the inclusion criteria of 103 samples contained in register BC data the PERABOI Padang. Survival analysis using Kaplan Meier with Log Rank Test. If the value of $p<0.05$ is obtained, there is a significant relationship. Results: There were differences between each clinical factor, biomolecular factor and therapeutic factor in terms of average DFS and OS average, but there was no statistically significant effect between therapeutic factors (hormone therapy, radiotherapy and target therapy) on DFS and OS in young BC patients in Padang City ( $p>0.05)$. There was an effect of giving chemotherapy to DFS in young breast cancer patients in Padang City $(p<0.05)$. Conclusion: There is no significant relationship between clinical factors and biomolecular factors with DFS and OS, but there is a significant relationship between the administration of chemotherapy with DFS and OS in young BC patients in the city of Padang in $2008-2018$.
\end{abstract}

Keywords: young breast cancer, breast cancer therapy, recurrence factor 
Affiliasi penulis: 1. Bagian IImu Bedah, Fakultas Kedokteran, Universitas Andalas, Padang, Indonesia. 2. IImu Kesehatan Masyrakat, Fakultas Kedokteran, Universitas Andalas, Padang, Indonesia.

Korespondensi: MagdiAyuza, Email: magdi_ayuza@yahoo.com Telp: +62853-6361-9983

\section{PENDAHULUAN}

Kanker payudara (KPD) merupakan kanker dengan insidensi tertinggi dibandingkan seluruh kanker pada wanita di seluruh dunia. Jumlah kasus baru KPD pada tahun 2018 yaitu sebesar 2.088.849 kasus atau sekitar $11,6 \%$ dari seluruh kanker di seluruh dunia. Angka kematian pada KPD sebesar 626.679 kasus $(6,6 \%)$ kasus kanker di seluruh dunia. KPD merupakan kanker yang paling sering didiagnosis pada berbagai negara (154 dari 185 negara) dan juga merupakan penyebab kematian terbanyak di lebih dari 100 negara di dunia. ${ }^{1}$

KPD menempati urutan kedua setelah kanker serviks di Indonesia. Data yang dipaparkan Kemenkes per 31 Januari 2019, terdapat angka KPD 42,1 per 100.000 penduduk dengan rata-rata kematian 17 per 100.000 penduduk. $^{2}$

Prevalensi kanker di Sumatera Barat tahun 2013 sebesar 1,7 per 1000 penduduk dan Sumatera Barat merupakan Provinsi ketiga dari 34 Provinsi tertinggi kejadian KPD dengan prevalensi sebesar 90 per 100.000 penduduk. Data Rekam Medik RSUP DR. M. Djamil Padang pada Irna Bedah tahun 2013, tercatat 160 kasus KPD, mengalami penurunan pada tahun 2014 yaitu 139 kasus dan pada tahun 2015 KPD mengalami peningkatan kembali yaitu 174 kasus. $^{3}$

Berdasarkan penelitian yang dilakukan oleh Hartaningsih dan Sudarsa di RSUP Sanglah tahun 2002 - 2012 menyatakan bahwa dari total 876 pasien, sekitar 199 pasien (22,7\%) adalah yang berusia $<40$ tahun, dengan kelompok usia mayoritas kasus KPD usia muda terjadi pada rentang usia 35-39 tahun, yakni sebesar $57,8 \% .{ }^{4}$

Berbagai studi yang ada, baik yang dilakukan secara prospektif maupun retrospektif, usia merupakan faktor prognostik independen dalam kejadian KPD yang berkaitan dengan angka ketahanan yang rendah. ${ }^{5,6}$ Keistimewaan KPD usia muda dari beberapa penelitian yang dilaporkan antara lain: 1) Memiliki karakter yang lebih agresif, antara lain: grade histologi lebih tinggi, komponen ER negatif lebih tinggi dan lebih banyak subtipe triple negatif 38 $\%$ dibanding yang tua $26 \%, 7,8$ 2) Memiliki outcome yang rendah pada KPD usia muda karena stadium klinis yang tinggi saat didiagnosa, tingginya angka KGB axila yang positif dan ukuran tumor yang lebih besar, ${ }^{9}$ 3) Memiliki angka rekurensi lebih dini dan Disease Free Survival dan Overal Survival yang lebih pendek dibandingkan KPD usia lebih tua. ${ }^{10}$

Tujuan pengobatan KPD adalah untuk mendapatkan: 1) Kesembuhan yang baik (cure rate yang tinggi) dalam arti kata disease free yang panjang dan sekaligus overall survival yang panjang pula, dan 2) Kualitas hidup penderita yang setinggi-tinggi nya. ${ }^{11}$ Untuk mencapai tujuan pengobatan tersebut, perlu ditentukan pilihan terapi yang tepat melalui analisis dari berbagai faktor yakni Prognostic Factor dan Prediktif Factor. ${ }^{11}$

Berbagai macam modalitas terapi KPD antara lain pembedahan, radioterapi, kemoterapi, terapi hormonal telah digunakan untuk tata laksana KPD. Namun, masih terdapat risiko terjadinya rekurensi pada KPD terutama pada pasien dewasa muda yaitu pasien dengan usia kurang dari 35 tahun. ${ }^{12,13}$

Adapun istilah rekurensi dalam hal ini merujuk pada keadaan munculnya kanker secara klinik yang telah diobati sebelumnya. Faktor penyebab terjadinya rekurensi setelah menjalani mastektomi karena dua alasan, yaitu karena penyebaran kanker itu sendiri atau karena tidak lengkapnya pengangkatan jaringan lokal dan regional. ${ }^{14}$

Prognostic Factor adalah setiap pengukuran atau nilai yang ada pada saat diagnosa dan berhubungan dengan Disease Free (masa bebas tumor) atau Over All Survival (harapan hidup); tanpa pemberian atau sebelum pemberian adjuvant terapi. ${ }^{11}$ Secara garis besar, faktor prognostik pada pasien KPD dapat dikelompokkan dalam 3 golongan yaitu: $11,15,16,17$

1. Faktor penderita, yang mempengaruhi survival adalah termasuk umur, ras / etnik, faktor sosioekonomi, gaya hidup dan co-morbidity

2. Faktor tumor, antara lain ukuran tumor, status kelenjar getah bening, tipe histopatologis, LVI (Lympovaskuler Invasion), dan imunohistokimia

3. Faktor lain yang berkaitan dengan terapi, seperti pengobatan terdahulu. 
Predictive Factor didefinisikan sebagai faktor faktor yang berhubungan dengan respon atau tidaknya terhadap sesuatu jenis terapi. Untuk Predictive Factor ini sendiri meliputi : 11

1. Stadium Tumor, berdasarkan sistem TNM (Tumor, Node, Metastase)

2. Histopatologi : tipe ; subtipe dan grading

3. Hormonal Dependency atau faktor hormonal, sangat dipengaruhi oleh kadar reseptor estrogen dan progesteron.

4. Keadaan umum penderita dan usia penderita

Secara klinis rekurensi lokal setelah mastektomi dijumpai adanya nodul yang asimptomatik dikulit dinding dada, didalam atau sekitar skar mastektomi, pada daerah flap kulit atau pada daerah dimana limfe node telah diangkat. Setelah radikal atau modified mastektomi daerah rekurensi mencakup regio yang dibatasi sternum didaerah medial, superior klavikula, lateral mid axila dan batas kosta diinferior. Rekurensi regional dapat terjadi bersama-sama dengan rekurensi lokal. ${ }^{16}$

\section{METODE}

Penelitian ini menggunakan desain cohort study retrospectif pada pasien KPD usia muda sebagai subjek penelitian yang dilakukan pada bulan Juli 2019 sampai November 2019. Penelitian dilakukan dengan analisis data dari register KPD PERABOI Padang yang berasal dari pasien yang diobati pada RSUP Dr M Djamil Padang, RS Ropana Suri, RS Ibnu Sina dan RS Siti Rahmah.

Populasi penelitian adalah semua subtipe KPD wanita usia muda yang diambil dari data register KPD PERABOI Padang yang berasal dari pasien yang diobati pada RSUP Dr M Djamil Padang, RS Ropana Suri, RS Ibnu Sina dan RS Siti Rahmah dengan total populasi 186 orang.
Pengambilan sampel dilakukan secara Confinience Sampling yaitu mengambil sampel penelitian yang terdapat pada data register KPD PERABOI Padang yang berasal dari pasien yang diobati RSUP Dr M Djamil Padang, RS Ropana Suri, RS Ibnu Sina dan RS Siti Rahmah. Semua pasien yang memenuhi kriteria inklusi akan diambil sampai besar sampel tercukupi.

Besar sampel dalam penelitian ini ditentukan dengan rumus Proporsi Diketahui. Kriteria inklusi berupa penderita KPD usia muda dengan semua stadium yang tercatat dan sudah didiagnosis secara histopatologis serta telah mendapatkan pengobatan KPD berupa operasi, kemoterapi, radioterapi, hormonal terapi dan targeting terapi yang memiliki data registerasi yang lengkap. Sementara kriteria ekslusi adalah KPD yang disertai kanker pada organ lain yang bukan metastasis dari KPD, KPD dengan penyakit penyerta, dan penderita KPD usia muda yang hilang dari follow-up.

Hubungan faktor usia, KGB axila, ukuran tumor, grading tumor, histopatologi, status LVI, status imunohistokimia terhadap DFS dan OS pada pasien KPD Usia muda menggunakan analisis bivariat. Analisis survival yang dipakai menggunakan Kaplan Meier dengan Log Rank Test. Penggunaan Kaplan Meier dengan Log Rank untuk melihat probabilitas survival. Apabila diperoleh nilai $p<0,05$, maka terdapat hubungan bermakna. Analisis data dilakukan menggunakan SPS.

\section{HASIL}

Penelitian ini dilakukan untuk mengetahui faktor-faktor yang mempengaruhi rekurensi KPD pada pasien dewasa muda di Kota Padang tahun 20082018. Data yang terkumpul setelah memenuhi kriteria inklusi dan eksklusi adalah sebanyak 103 pasien. 
Tabel 1. Pengaruh Faktor Klinis terhadap DFS dan OS pada Pasien KPD Usia muda di Kota Padang

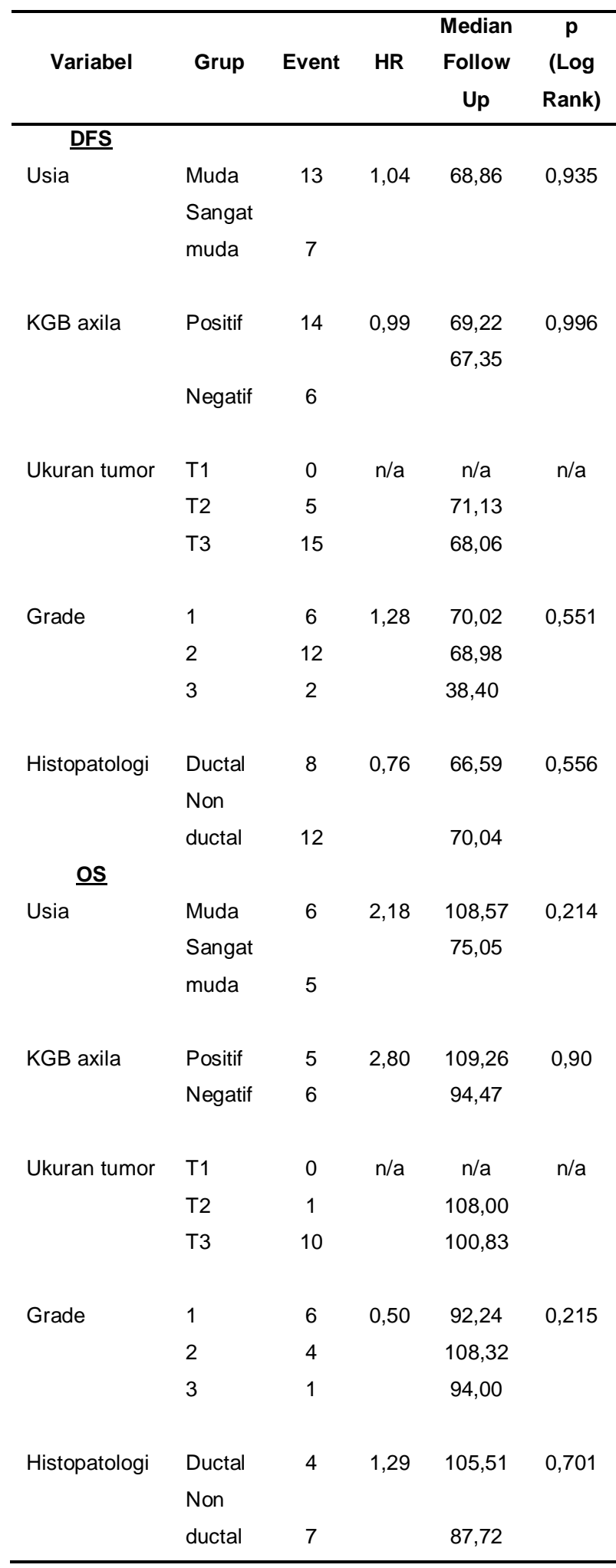

Pada Tabel 1 terlihat bahwa terdapat perbedaan yang cukup nyata dalam hal kekambuhan terkait grading tumor. Adapun untuk faktor usia, KGB axila, ukuran tumor dan histopatologi, walapun memiliki perbedaan dalam hal kekambuhan, namun perbedaannya tidak terlalu signifikan.
Tabel 2. Pengaruh Faktor Biomolekuler terhadap DFS dan OS pada Pasien KPD Usia muda di Kota Padang

\begin{tabular}{|c|c|c|c|c|c|}
\hline Variabel & Grup & Event & HR & $\begin{array}{c}\text { Median } \\
\text { Follow } \\
\text { Up }\end{array}$ & $\begin{array}{c}p \\
\text { (Log } \\
\text { Rank) }\end{array}$ \\
\hline \multicolumn{6}{|l|}{ DFS } \\
\hline \multirow[t]{2}{*}{ LVI } & Negatif & 19 & 3,39 & 67,26 & 0,233 \\
\hline & Positif & 1 & & 68,31 & \\
\hline \multirow[t]{2}{*}{ ER } & Negatif & 14 & 0,95 & 69,87 & 0,914 \\
\hline & Positif & 6 & & 60,49 & \\
\hline \multirow[t]{2}{*}{ PR } & Negatif & 15 & 1,44 & 68,12 & 0,480 \\
\hline & Positif & 5 & & 53,75 & \\
\hline \multirow[t]{2}{*}{ Her2 } & Negatif & 12 & 0,59 & 71,09 & 0,244 \\
\hline & Positif & 8 & & 63,45 & \\
\hline \multirow[t]{2}{*}{ KI67 } & $\geq 20 \%$ & 6 & 1,08 & 42,79 & 0,873 \\
\hline & $<20 \%$ & 14 & & 68,51 & \\
\hline \multirow[t]{4}{*}{ IHK } & $\mathrm{ER}+/ \mathrm{PR}+$ & 4 & 1,06 & 54,28 & 0,744 \\
\hline & $\mathrm{ER}+/ \mathrm{PR}-$ & 2 & & 46,00 & \\
\hline & ER-/PR+ & 1 & & 44,40 & \\
\hline & ER-/PR- & 13 & & 69,32 & \\
\hline \multirow[t]{4}{*}{ Subtipe } & Luminal A & 4 & 0,93 & 51,99 & 0,684 \\
\hline & Luminal B & 3 & & 53,14 & \\
\hline & Erb2 & 6 & & 61,03 & \\
\hline & TNBC & 7 & & 73,52 & \\
\hline
\end{tabular}

\section{$\underline{\text { OS }}$}

\begin{tabular}{|c|c|c|c|c|c|}
\hline \multirow[t]{2}{*}{ LVI } & Negatif & 11 & $\mathrm{n} / \mathrm{a}$ & 45,07 & $\mathrm{n} / \mathrm{a}$ \\
\hline & Positif & 0 & & $\mathrm{n} / \mathrm{a}$ & \\
\hline \multirow[t]{2}{*}{ ER } & Negatif & 11 & $\mathrm{n} / \mathrm{a}$ & 53,46 & $\mathrm{n} / \mathrm{a}$ \\
\hline & Positif & 0 & & $\mathrm{n} / \mathrm{a}$ & \\
\hline \multirow[t]{2}{*}{ PR } & Negatif & 11 & $\mathrm{n} / \mathrm{a}$ & 48,37 & $\mathrm{n} / \mathrm{a}$ \\
\hline & Positif & 0 & & $\mathrm{n} / \mathrm{a}$ & \\
\hline \multirow[t]{2}{*}{ Her2 } & Negatif & 9 & 1,88 & 100,47 & 0,423 \\
\hline & Positif & 2 & & 79,22 & \\
\hline \multirow[t]{2}{*}{ KI67 } & $\geq 20 \%$ & 1 & 3,58 & 47,03 & 0,236 \\
\hline & $<20 \%$ & 10 & & 101,57 & \\
\hline \multirow[t]{4}{*}{ IHK } & $\mathrm{ER}+/ \mathrm{PR}+$ & 1 & $\mathrm{n} / \mathrm{a}$ & 47,54 & $\mathrm{n} / \mathrm{a}$ \\
\hline & ER+/PR- & 0 & & $\mathrm{n} / \mathrm{a}$ & \\
\hline & ER-/PR+ & 0 & & $\mathrm{n} / \mathrm{a}$ & \\
\hline & ER-/PR- & 10 & & 46,91 & \\
\hline \multirow[t]{4}{*}{ Subtipe } & Luminal A & 0 & $\mathrm{n} / \mathrm{a}$ & $\mathrm{n} / \mathrm{a}$ & $\mathrm{n} / \mathrm{a}$ \\
\hline & Luminal B & 0 & & $\mathrm{n} / \mathrm{a}$ & \\
\hline & Erb2 & 2 & & 48,07 & \\
\hline & TNBC & 9 & & 44,45 & \\
\hline
\end{tabular}

${ }^{*} \mathrm{n} / \mathrm{a}$, not available 
Ketahanan hidup (OS) mendapatkan faktor usia memiliki perbedaan yang cukup signifikan. Adapun untuk faktor klinis berupa KGB axila, ukuran tumor dan grading, memiliki perbedaan dalam hal ketahanan hidup, namun tidak signifikan.

Pada Tabel 1 diketahui tidak terdapat pengaruh faktor klinis (usia, KGB axila, ukuran tumor, grading tumor dan histopatologi) terhadap DFS dan OS pada pasien KPD usia muda di Kota Padang ( $p>0,05)$.

Tabel 2 memperlihatkan ada perbedaan dalam hal kekambuhan terkait kelompok subtipe KPD pada usia muda. Dimana subtipe TNBC memiliki angka kekambuhan yang lebih lama (rata-rata 73 bulan) dibandingkan subtipe lain. Dan untuk angka ketahanan hidup, kelompok dengan Ki67 $\geq 20 \%$, memiliki angka ketahanan hidup yang lebih rendah (yakni 47 bulan) dibandingkan dengan kelompok Ki67 $<20 \%$ (yakni 101 bulan).

Analisis statistik pada Tabel 3 tidak terdapat pengaruh yang bermakna antara faktor biomolekuler (status LVI, status imunohistokimia dan subtipe) terhadap DFS dan OS pada pasien KPD usia muda di Kota Padang ( $p>0,05)$.

Pada Tabel 3 tampak perbedaan antara pasien yang diberikan kemoterapi, terapi hormonal, target terapi dan radioterapi dalam hal ketahanan hidup. Namun dari Tabel 3 diketahui tidak terdapat pengaruh yang bermakna secara analisis statistik antara faktor terapi (terapi hormon, radioterapi dan terapi target) terhadap DFS dan OS pada pasien KPD usia muda di Kota Padang $(p>0,05)$. Akan tetapi terdapat pengaruh dari pemberian kemoterapi terhadap DFS pada pasien KPD usia muda di Kota Padang $(p<0,05)$, dimana median follow up pada pasien yang diberikan kemoterapi yaitu 69,69 bulan lebih tinggi dibandingkan yang tidak diberikan kemoterapi yaitu 64,76 bulan, dengan $\mathrm{HR}=0,54$.
Tabel 3. Pengaruh Faktor Terapi terhadap DFS dan OS pada Pasien KPD Usia muda di Kota Padang

\begin{tabular}{|c|c|c|c|c|c|}
\hline Variabel & Grup & Event & HR & $\begin{array}{c}\text { Median } \\
\text { Follow } \\
\text { Up } \\
(95 \% \\
\text { Cl) }\end{array}$ & $\begin{array}{c}p(\log \\
\text { rank } \\
\text { test) }\end{array}$ \\
\hline \multicolumn{6}{|l|}{$\underline{\text { DFS }}$} \\
\hline \multirow[t]{2}{*}{ Kemoterapi } & $\begin{array}{l}\text { Tidak } \\
\text { kemo }\end{array}$ & 1 & 0,54 & 64,76 & $0,043^{*}$ \\
\hline & Kemoterapi & 19 & & 69,69 & \\
\hline \multirow[t]{2}{*}{$\begin{array}{l}\text { Terapi } \\
\text { hormone }\end{array}$} & $\begin{array}{l}\text { Tidak } \\
\text { diberi }\end{array}$ & 12 & 0,86 & 70,55 & 0,733 \\
\hline & Diberikan & 8 & & 67,78 & \\
\hline \multirow[t]{2}{*}{ Radioterapi } & $\begin{array}{l}\text { Tidak } \\
\text { diberi }\end{array}$ & 15 & 0,45 & 70,94 & 0,125 \\
\hline & Diberikan & 5 & & 57,51 & \\
\hline $\begin{array}{l}\text { Terapi } \\
\text { target }\end{array}$ & $\begin{array}{l}\text { Tidak } \\
\text { diberi }\end{array}$ & 15 & 0,42 & 70,59 & 0,096 \\
\hline$\underline{\text { os }}$ & \multicolumn{4}{|c|}{$\underline{\text { os }}$} & \\
\hline \multirow[t]{2}{*}{ Kemoterapi } & $\begin{array}{l}\text { Tidak } \\
\text { diberi }\end{array}$ & 5 & 2,89 & 91,01 & 0,084 \\
\hline & Diberikan & 6 & & 108,55 & \\
\hline \multirow[t]{2}{*}{$\begin{array}{l}\text { Terapi } \\
\text { hormon }\end{array}$} & $\begin{array}{l}\text { Tidak } \\
\text { diberi }\end{array}$ & 10 & & 94,89 & \\
\hline & Diberikan & 1 & 6,71 & 116,56 & 0,071 \\
\hline \multirow[t]{2}{*}{ Radioterapi } & $\begin{array}{l}\text { Tidak } \\
\text { diberi }\end{array}$ & 11 & $\mathrm{n} / \mathrm{a}$ & 60,00 & $\mathrm{n} / \mathrm{a}$ \\
\hline & Diberikan & 0 & & $\mathrm{n} / \mathrm{a}$ & \\
\hline \multirow[t]{2}{*}{$\begin{array}{l}\text { Terapi } \\
\text { target }\end{array}$} & $\begin{array}{l}\text { Tidak } \\
\text { diberi }\end{array}$ & 10 & 1,66 & 102,63 & 0,630 \\
\hline & Diberikan & 1 & & 79,39 & \\
\hline
\end{tabular}

Pada Kaplan-meier faktor kemoterapi terhadap DFS pada pasien KPD usia muda di Kota Padang dapat dilihat pada Gambar 1. 
Survival Functions

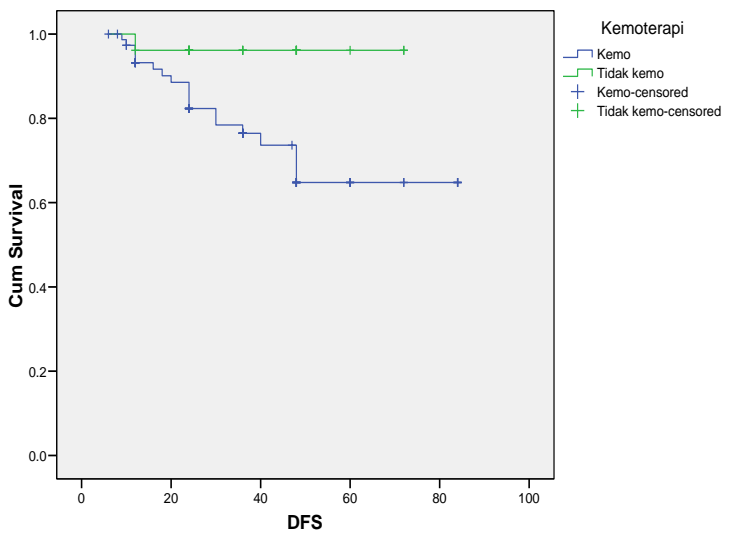

Gambar 1. Kaplan-meier Faktor Kemoterapi terhadap DFS pada Pasien KPD Usia muda di Kota Padang

Pada Gambar 1 terlihat grafik Kaplan-meier terbentuk proporsional dan mampu menjelaskan pengaruh antara pemberian kemoterapi terhadap DFS pada pasien KPD usia muda di Kota Padang.

\section{PEMBAHASAN}

Pada 103 sampel didapatkan 92 sampel masih hidup sampai akhir periode penelitian, dan sebanyak 11 sampel meninggal selama periode penelitian. Pada penelitian ini juga didapatkan 83 pasien tidak mengalami kekambuhan selama periode penelitian, dan hanya 20 pasien yang mengalami kekambuhan.

Kelompok usia menunjukkan perbedaan dalam rata-rata DFS dan OS bila dikaitakan dengan usia penderita KPD, namun secara analisis statistik menunjukkan tidak terdapat hubungan yang bermakna antara usia penderita KPD dengan DFS $(p=0,935)$ dan OS $(p=0,214)$. Hasil ini senada dengan penelitian yang didapatkan oleh Aryandono et al (2006) dan Lin et al (2019) dimana secara analisis statistik tidak didapatkannya hubungan yang bermakna antara usia dengan DFS dan OS. ${ }^{18,19}$

$\mathrm{Hal}$ ini berbeda dengan penelitian yang dilakukan Fora, dimana dari analisis statistik menunjukkan terdapat hubungan yang bermakna antara usia penderita dengan DFS $(p=0,002)$ dan OS $(p=0,028) .{ }^{20}$ Penelitian yang dilakukan oleh Zhao et al (2015) dan Gnerlich et al (2008), juga menyatakan terdapat hunbungan antara usia penderita KPD dengan DFS dan OS. ${ }^{21,22}$
Pada penelitian ini didapatkan pasien dengan KGB axila positif sebanyak 14 pasien mengalami kekambuhan, dan kelompok pasien dengan KGB Axila negatif, terjadi kekambuhan sebanyak 6 pasien, dengan rata-rata kambuh dalam 69,22 bulan. Adapun rata-rata OS dari penelitian ini didapatkan yakni 109,26 bulan. Dari analisa statistik menggunakan kaplan meier, didapatkan bahwa tidak terdapat hubungan bermakna antara KGB Axila dengan DFS maupun OS pada penderita KPD usia muda $(p=$ 0,996). Hal ini berbeda dengan penelitian yang dilakukan oleh Fora, dimana didapatkan adanya hubungan bermakna antara KGB Axila dengan DFS $(p=0,013)$ dan OS $(P=0,029) \cdot{ }^{20}$ Hasil senada juga dari penelitian Aryandono (2006), mendapatkan hubungan bermakna antara KGB Axila dengan DFS dan OS. ${ }^{18}$

Fredholm et al (2009) menyatakan bahwa ratarata OS pada kelompok KGB Axila negatif lebih lama dibandingkan dengan kelompok KGB Axila positif. ${ }^{23}$ Hal senada dengan penelitian oleh Lin et al, yakni terdapat hubungan yang bermakna antara KGB Aksila dengan DFS dan OS. ${ }^{19}$

Analisis statistik menunjukkan tidak terdapat hubungan yang bermakna antara DFS dan OS dengan ukuran tumor ( $P>0.05)$. Dari penelitian sebelumnya, yang dilakukan Fora, juga didapatkan tidak adanya hubungan yang nyata antara ukuran tumor dengan DFS dan OS pada pasien KPD usia muda (dengan p> 0,005). ${ }^{20}$ Hasil ini sejalan dengan hasil Penelitian yang dilakukan oleh Lin et al , dimana tidak terdapatnya hubungan yang bermakna antara ukuran tumor dengan DFS $(P=0,053)$ dan OS $(p=0,028) \cdot{ }^{19} \mathrm{Hal}$ ini berbeda dengan penelitian yang dilakukan Aryandono et al (2006) dan Xiao Zhang et al bahwa terdapat hubungan yang bermakna antara ukuran tumor dengan DFS dan OS, dimana semakin besar tumor, semakin berkurang angka kekambuhan dan ketahan hidup. ${ }^{18,6}$

Hasil penelitian ini mendapatkan tidak terdapat hubungan bermakna antara grade (derajat difrensiasi) dengan DFS dan OS pada penderita KPD usia muda. Angka kekambuhan terbanyak timbul pada kelompok difrensiasi sedang. Hasil ini sejalan dengan penelitian 
yang dilakukan oleh Fora dan Lin et al, dimana tidak terdapatnya hubungan yang bermakna antara grade (derajat diferensiasi) tumor dengan DFS dan OS. ${ }^{20,19}$ Hasil ini berbeda dengan penelitian Anders et al dan Dillon et al, yang menyatakan terdapat hubungan antara grade tumor dengan angka kekambuhan KPD pada usia muda. ${ }^{5,24}$

Dari hasil penelitian didapatkan tidak terdapat hubungan bermakna antara jenis histopatologi tumor dengan DFS $(P=0,55)$ dan OS $(P=0,7)$ pada pasien penderita KPD usia muda di kota Padang. Pada penelitian yang dilakukan sebelumnya oleh Fora, juga didapatkan bahwa tidak terdapat hubungan bermakna antara histopatologi dengan DFS ( $p=0,887)$ dan OS $(p=0,956) .{ }^{20}$ Hasil ini sejalan dengan hasil Penelitian yang dilakukan oleh Lin et al, dimana tidak terdapatnya hubungan yang bermakna antara jenis histopatologi tumor dengan DFS $(p=0,07)$ dan OS $(p=0,289) .{ }^{19}$ Hal serupa juga didapatkan pada penelitian yang dilakukan oleh Zhao et al (2006 2012), dimana dari penelitian ini tidak terdapat hubungan yang bermakna antara jenis histopatologi dengan DFS dan OS penderita KPD usia muda dengan $p=0,56 .{ }^{21}$ Tidak bermaknanya hubungan antara histopatologi dengan ketahanan hidup disebabkan oleh adanya faktor lain seperti efek samping dari adjuvan terapi. ${ }^{18}$

Hasil penelitian ini menunjukkan tidak terdapat pengaruh faktor biomolekuler (status LVI, status imunohistokimia dan subtipe) terhadap DFS dan OS pada pasien KPD usia muda di Kota Padang $(p>0,05)$.

Dalam sebagian besar penelitian, tingginya tingkat invasi limfovaskular (LVI) menunjukkan hubungan yang erat dengan penanda prognosis yang buruk. Kehadiran LVI dapat memprediksi hasil yang lebih buruk untuk pasien dengan KPD invasif. LVI juga dapat digunakan sebagai indikator perilaku agresif dan kemampuan metastasis (nodal dan sistemik) dari keganasan primer $^{25,26}$ dan juga LVI adalah faktor prognostik yang merugikan baik kambuh dan kelangsungan hidup pada pasien yang KGB negatif diobati dengan mastektomi dan terapi sistemik. ${ }^{26}$

Freedman et al melaporkan bahwa LVI yang disertai dengan faktor prognostik buruk lainnya, tetapi LVI sendiri bukanlah penentu independen dalam hal perulangan regional lokal atau kelangsungan hidup dalam analisis multivariat. LVI terdokumentasikan dengan baik pada tumor payudara, meskipun merupakan penanda prognosis yang buruk, namun tidak ada konsensus dalam literatur tentang hal ini. Setelah analisis univariat, ditemukan bahwa LVI memperpendek kelangsungan hidup secara keseluruhan, namun, LVI tidak ditemukan mempengaruhi kelangsungan hidup secara keseluruhan dalam analisis multivariat. ${ }^{27}$

Pada hasil penelitian tidak terdapat hubungan bermakna antara hormonal receptors dengan DFS dan OS. Namun pasien dengan kombinasi ER -/PR memiliki angka kekambuhan paling tinggi dibanding kombinasi yang lain. Hal ini sama dengan hasil penelitian yang dilakukan oleh Fora, bahwa tidak terdapat hubungan antara Hormonal reseptor dengan DFS dan OS. ${ }^{20} \mathrm{Hal}$ ini berbeda dengan penelitian yang dilakukan Anders et al (2008) menemukan bahwa KPD usia muda berhubungan dengan rendahnya $E R$ positivity $(\mathrm{p}=0,027) .^{5} \quad$ Adapun penelitian yang dilakukan Zhao et al, didapatkan bahwa terdapat hubungan antara reseptor hormonal dengan DFS dan OS pada penderita 119 penderita KPD usia muda. ${ }^{28}$

Penderita dengan ER positif ternyata mempunyai perbedaan angka bebas kekambuhan lebih lama dibanding penderita dengan ER negatif, sebesar $10 \%$ dalam lima tahun. Ekspresi negatif dari ER dan atau PR pada KPD juga didapatkan outcome yang buruk dikarenakan resisten-nya terhadap terapi hormonal. ${ }^{15}$

Dari penelitian ini diketahui tidak terdapat pengaruh faktor terapi (terapi hormon, radioterapi dan terapi target) terhadap DFS dan OS pada pasien KPD usia muda di Kota Padang ( $p>0,05)$. Namun terdapat pengaruh pada pemberian kemoterapi terhadap DFS pasien KPD usia muda di Kota Padang $(p<0,05)$, dimana median follow up pada pasien yang diberikan kemoterapi yaitu 69,69 bulan lebih tinggi dibandingkan yang tidak diberikan kemoterapi yaitu 64,76 bulan, dengan $\mathrm{HR}=0,54$.

Hal ini dikarenakan berdasarkan pemeriksaan imunohistokimia pada penelitian ini, didapatkan kombinasi yang paling banyak adalah ER-/PR$(64,1 \%)$, dan kurang dari hampir setengah dari responden memiliki subtipe TNBC (48,5\%). Sehingga 
hal ini sudah sesuai dengan protokol terapi untuk KPD, berdasarkan Rekomendasi dari St. Gallen Consensus Conference 2011, dikatakan bahwa terapi pilihan berdasarkan kelompok reseptor hormonal, untuk kelompok ER - dan PR -, serta subtipe TNBC, adalah cytotoxic (kemoterapi). ${ }^{29}$

\section{SIMPULAN}

Tidak terdapat hubungan yang bermakna antara Faktor Klinis (usia, KGB axila, ukuran tumor, grading tumor dan histopatologi), Faktor Biomolekuler (Status LVI, Status Imunohistokimia) dan faktor terapi (radioterapi, hormonal terapi dan target terapi) terhadap DFS dan OS penderita KPD usia muda di kota Padang tahun 2008 - 2018, namun terdapat hubungan bermakna antara pemberian kemoterapi dengan DFS dan OS pada penderita KPD usia muda di kota Padang tahun $2008-2018$.

\section{SARAN}

Perlu dicari faktor lain (seperti faktor gaya hidup, pola makanan, faktor keluarga) yang mungkin mempengaruhi DFS dan OS kanker payudara usia muda.

\section{KONFLIK KEPENTINGAN}

Tidak ada konflik kepentingan (Publik interest) dalam penelitian ini.

\section{UCAPAN TERIMA KASIH}

Terima kasih saya kepada Dr. dr. Daan Khambri, SpB (K) Onk sebagai Ketua PERABOI Padang yang telah memberikan fasilitas dan kesempatan kepada untuk melakukan penelitian dan pengumpulan data di PERABOI Padang.

\section{DAFTAR PUSTAKA}

1. Feng $\mathrm{Y}$, Spezia M, Huang S, Yuan C, Zeng Z, Zhang $L$, et al. Breast cancer development and progression: risk factors, cancer stem cells, signaling pathways, genomics, and molecular pathogenesis. Genes \& Diseases. 2018; 5(2): 77-106.

2. Pusat Data dan Informasi Kemenkes RI. Data dan informasi kesehatan situasi penyakit kanker. Buletin Jendela Data dan Informasi Kesehatan edisi Kanker. $2015 ; 1(1)$.

3. Sari SE, Harahap WA, Saputra D. Pengaruh faktor risiko terhadap ekspresi reseptor estrogen pada penderita kanker payudara di kota Padang. Jurnal Kesehatan Andalas. 2018; 7(4):461-8.

4. Hartaningsih D, Sudarsa I. Kanker payudara pada wanita usia muda di bagian bedah onkologi rumah sakit umum pusat Sanglah Denpasar tahun 2002 - 2012. E-Jurnal Medika Udayana. 2014: 3(6).

5. Anders CK, Hsu DS, Broadwater G, Acharya CR, Foekens JA, Zhang $\mathrm{Y}$, et al. Young age at diagnosis correlates with worse prognosis and defines a subset of breast cancers with shared patterns of gene expression. Journal of Clinical Oncology. 2008;26(20):3324-30.

6. Zhang $\mathrm{X}$, Yang J, Cai H, Ye Y. Young age is an independent adverse prognostic factor in early stage breast cancer: a population-based study. Cancer Management And Research. 2018; 10 : 4005-18.

7. Morrison DH, Rahardja D, King E, Peng $\mathrm{Y}$, Sarode VR. Tumour biomarker expression relative to age and molecular subtypes of invasive breast cancer. British Journal of Cancer. 2012;107(2):382-7.

8. Carvalho FM, Bacchi LM, Santos PPC, Bacchi CE. Triple-negative breast carcinomas are a heterogeneous entity that differs between young and old patients. Clinical Science. 2010; 65 (10): 1033-6.

9. Gabriel C, Domchek S. Breast cancer in young women. Breast Cancer Research. 2010;12(5): 212.

10. Bacchi LM, Corpa M, Santos PP, Bacchi CE, Carvalho FM. Estrogen receptor-positive breast carcinomas in younger women are different from those of older women: a Pathological And Immunohistochemical Study. The Breast Elsevier 2010;19(2):137-41.

11. Ramli M. Update breast cancer management diagnostic and treatment. Majalah Kedokteran Andalas. Agustus 2015;38(Suppl.1):28-53.

12. Chen $X$, Liu L, Wang $Y$, Liu $B$, Zeng $D$, Jin $Q$, et al. Identification of breast cancer recurrence risk factors based on functional pathways in tumor 
and normal tissues. Impact Journal.Oncotarget. 2017;8(13):20679-94.

13. Shahriari-Ahmadi A, Arabi M, Payandeh M, Sadeghi M. The recurrence frequency of breast cancer and its prognostic factors in Iranian patients. International Journal Applied and Basic Medical Research. 2017;7(1):40.

14. Donegan W. Prognostic factors. stage and receptor status in breast cancer. Cancer. 1992; 70:1755-64.

15. Moffat FL. Clinical and prognostic and predictive factors. In: Harris J, editor. Disease of the Breast. Philadelphia: $5^{\text {th }}$ edition. Wolters Kluwer Health Publishers; 2014. p. 439-51.

16. Devita V, Laurence T, Rosenberg S. Principles and practice of oncology. 11th ed. Philadelphia: Lippincot-Raven; 2015.p. 2150-250.

17. Soerjomataram I, Louwman MWJ, Ribot JG, Roukema JA, Coebergh JWW. An overview of prognostic factors for long-term survivors of breast cancer. Breast Cancer Research and Treatment. 2008;107(3):309-30.

18. Aryandono T. Faktor prognosis kanker payudara operabel di Yogyakarta [disertasi]. Yogyakarta: Fakultas Kedokteran, Universitas Gajah Mada; 2006.hlm.188.

19. Lin HUI, Zhang FAN, Wang L, Zeng DE. Use of clinical nomograms for predicting survival outcomes in young women with breast cancer. Oncology Letter. 2019;17(2):1505-16.

20. Fora A. Analisis survival pasien kanker payudara usia muda di kota Padang tahun 2011-2016 [tesis]. Padang: Program Pendidikan Dokter Spesialis IImu Bedah, Fakultas Kedokteran Universitas Andalas; 2017.

21. Zhao $Y$, Dong $X$, Li R, Song J, Zhang D. Correlation between clinical-pathologic factors and long-term follow-up in young breast cancer patients. Translational Oncology. 2015;8(4): 26572.

22. Gnerlich JL, Deshpande AD, Jeffe DB, White N, Margenthaler JA. Elevated breast cancer mortality in young women ( $<40$ years) compared with older women is attributed to poorer survival in early stage disease. American College of Surgeons Clinical Congress.October 2009:341-7

23. Fredholm H, Eaker S, Frisell J, Holmberg L, Fredriksson I, Lindman $\mathrm{H}$. Breast cancer in young women: poor survival despite intensive treatment. breast cancer research and treatment. PLOS One Journal. 2009;4(11):1-9.

24. Dillon D, Guidi A, and Schnitt S. Pathology of invasive breast cancer. In Harris J, Lippman M, Morrow M (editor). Diseases Of The Breas. Philadelphia: $5^{\text {th }}$ edition. Wolters Kluwer Health Publishers; 2014. p. 381-410.

25. Gurleyik G, Gurleyik E, Aker F, Aktekin A, Emir $S$, Gungor $\mathrm{O}$, et al. Lymphovascular invasion, as a prognostic marker in patients with invasive breast cancer. Acta Chirurgica Belgia. 2007; 107 (3):284-7.

26. Truong PT, Yong CM, Abnousi F, Lee J, Kader $\mathrm{HA}$, Hayashi $A$, et al. Lymphovascular invasion is associated with reduced locoregional control and survival in women with node - negative breast cancer treated with mastectomy and systemic therapy. Journal American Collage Surgeon. 2005;200(6):912-21.

27. Freedman GM, Li T, Polli L V., Anderson PR, Bleicher RJ, Sigurdson E, et al. Lymphatic space invasion is not an independent predictor of outcomes in early stage breast cancer treated by breast-conserving surgery and radiation. The Breast Journal. 2012;18(5):415-9.

28. Zhao $Y$, Wang $X$, Huang $Y$, Zhou X, Zhang D. Conversion of immunohistochemical markers and breast density are associated with pathological response and prognosis in very young breast cancer patients who fail to achieve a pathological complete response after neoadjuvant chemotherapy. Cancer Management and Research. 2019;11:5677-90.

29. Purwanto H, Handoyo D, Haryono S, Harahap W. Panduan penatalaksanaan kanker payudara. Jakarta: PERABOI; 2015. hlm.15-21. 